\title{
COMPUTER MEDIATED COMMUNICATION (CMC) DALAM PEMBELAJARAN BAHASA INGGRIS
}

\author{
Oleh: \\ Risma Fahrul Amin \\ Universitas Ibrahimy Situbondo, Indonesia \\ rismafahrulamin@gmail.com
}

\begin{abstract}
:
The Industrial Revolution 4.0 has produced many breakthroughs especially the appearance of communication platforms that gave colour to English learning in Indonesia. Therefore computers are very useful in language class, although basically computers are only tools for mediating student's communication in English learning. This paper describes Computer Mediated Communication (CMC) in English learning.
\end{abstract}

Keywords: Pembelajaran Bahasa Inggris, Computer Mediated Communication (CMC)

\section{A. Pendahuluan}

Dunia telah memasuki era globalisasi, di mana peran bahasa terutama bahasa Inggris dan peran teknologi khususnya Instructional Computer Technology (ICT) sangat dominan. Kedua elemen ini berkembang begitu kuat dan harus dikonsumsi dalam semua bidang pendidikan modern. Jadi diperlukan sistem interaksi yang tepat untuk menyatukan dua komponen, yang merupakan aktualisasi dari bahasa dan kecanggihan komputer. Dalam hal ini pendekatan yang paling cocok dan komprehensif adalah Computer Assisted Language Learning (CALL) sebagai interaksi sistemik dalam proses pengajaran bahasa Inggris yang termasuk didalamnya terdapat Computer Mediated Commmunication (CMC). ${ }^{1}$

Computer Mediated Commmunication (CMC) merupakan komunikasi manusia yang terjadi melalui penggunaan dua atau lebih perangkat elektronik. Meskipun istilah ini secara tradisional diartikan sebagai komunikasi yang terjadi melalui format media komputer (seperti: instant messaging, email, chat room, online forum, social network

1 Amin, R.F. Computer Assisted Language Learning (CALL): Konsep Pembelajaran Bahasa Inggris Berbantuan Komputer. LISAN AL-HAL, Jurnal Pengembangan Pemikiran dan Kebudayaan, Vol. 8, No.2, (2016), 281-298. 
services), hal ini juga telah diaplikasikan ke dalam bentuk media interaksi berbasis teks lainnya seperti pesan teks atau chat dengan handphone.

Perkembangan komputer serta meluasnya penggunaan jaringan internet telah mengubah Computer Mediated Communication (CMC) menjadi media komunikasi yang sangat penting yang telah digunakan secara bebas dan efektif mencakup berbagai tujuan termasuk komunikasi antarpribadi, transfer informasi, tujuan pedagogis, dll. Integrasi teknologi dalam pendidikan diharapkan memberi banyak efek positif pada pembelajaran dan pengajaran bahasa. Telah terbukti bahwa komunikasi berbasis internet secara signifikan berdampak pada motivasi siswa ${ }^{2}$ yang menghasilkan peningkatan keterampilan komunikatif siswa baik secara lisan maupun tulis. ${ }^{3}$ Menurut Fey ${ }^{4}$ dan Boone ${ }^{5}$, pembelajaran bahasa berbasis teknologi telah merevolusi dunia pendidikan dan memungkinkan untuk melampaui batas dinding ruang kelas untuk belajar dengan cara baru. Oleh karena itu, perlu untuk mengeksplorasi lebih lanjut kelebihan dan potensi yang ditawarkan media ini. Menurut Quan-Hasse, Cothrel, dan Wellman ${ }^{6}$, teknologi komputer memungkinkan peserta didik untuk mengkomunikasikan ide, informasi, dan perasaan mereka tanpa batas ruang dan waktu.

Computer-Mediated Communication (CMC) dengan penggunaan Internet muncul sebagai sumber daya utama pembelajaran bahasa Inggris. Dalam aplikasi CMC, penggunaan komputer dengan koneksi Internet memungkinkan komunikasi orang-ke-orang pada berbagai materi bahasa Inggris menggunakan electronic mail, news groups, chat rooms dan professional on-line discussion groups. Penggunaan ini melibatkan

2 Warschauer, M. Motivational Aspects of Using Computers For Writing And Communication. In M. Warschauer (Ed.), Telecollaboration in foreign language learning: Proceedings of the Hawai'i Symposium, (1996), 29-46.

3 Meunier, L. E. Personality Differences And Motivational Factors In Distance Learning. In F. Borchardt, C. Bradin, \& E. Jonhson (Eds.), Distance learning, Proceedings of the Computer Assisted Language Instruction Consortium 1996 Annual Symposium, (1996), 181-188.

4 Fey, M. Critical Literacy In School-College Collaboration Through Computer Networking: A Feminist Research Project. Journal of Literacy Research, 30(1), (1998), 85117.

5 Boone, K. C. Speech Or Writing? Email As A New Medium. Liberal Education, 87(3), 2001, 54-58.

${ }^{6}$ Quan-Hasse, A., Cothrel, J., \& Wellman, B. Instant Messaging for Collaboration: A Case Study of a High-Tech Firm. Journal of Computer Mediated Communications, 10(4), (2005). Retrieved May 9, 2007, from http://jcmc.indiana.edu/vol10/issue4/quanhaase.htm

$342 \mid$ JURNAL LISAN AL-HAL 
komunikasi cetak dan audio antara peserta. ${ }^{7}$

Peluang untuk komunikasi antara siswa ke siswa dikelas terbatas, dan ketika siswa diminta untuk berkomunikasi secara lisan di kelas dalam bahasa kedua (bahasa Inggris), mereka mungkin takut membuat kesalahan atau dinilai negatif. Oleh karena itu, mereka mungkin merasa tidak termotivasi dalam berbicara secara individu di kelas dengan teman sekelas atau guru mereka. Tantangan dalam pengembangan kelas bahasa Inggris tersebut membuat pengajar bahasa Inggris mencoba menemukan lingkungan belajar interaktif yang otentik sebagai alternatif dimana siswa mereka dapat berkomunikasi dengan siswa lain dalam bahasa target (bahasa Inggris). CMC tampaknya menawarkan kesempatan seperti itu untuk komunikasi siswa-ke-siswa yang cukup bebas dalam lingkungan yang memotivasi. ${ }^{8}$

CMC menawarkan kemungkinan bagi peserta didik bahasa Inggris untuk menemukan partner chat interkultural berbasis suara / berbasis teks dan untuk berpartisipasi dalam diskusi pembelajaran jarak jauh berdasarkan topik yang diminati bersama. Belajar tidak lagi terkekang dalam ruang dan waktu; sebaliknya, melalui CMC, peserta didik mendapat kesempatan untuk berkomunikasi dan belajar secara kolaboratif dengan peserta didik di seluruh dunia. ${ }^{910}$ Fotos $^{11}$ mengklaim bahwa CMC dapat mengubah sikap negatif siswa terhadap pelajaran speaking dan pembelajaran bahasa Inggris itu sendiri.

Aplikasi komputer terbaru untuk pengajaran bahasa telah memanfaatkan kapasitas jaringan teknologi komputer yang lebih menekankan pada pengintegrasian skill (reading, listening, speaking dan writing) dalam pembelajaran dan penggunaan bahasa, dan yang lebih penting adalah pengintegrasian peserta didik dalam lingkungan

7 Selinger, M. Forming a critical community through telematics. Computers Education, 30 (1/2), (1998), 23-30.

8 Tanian, S. \& James, K.. Could Oral Communication Skills Become A Casualty Of Online Learning?: A Future Scenario That Could Prevent This. Herdsa 2002 conference, (2002), 634-639.

${ }^{9}$ Kern, R. G. Restructing Classroom Interaction With Networked Computers: Effects On Quantity And Characteristics Of Language Production. The Modern Language Journal, 79(4), (1996), 457-476.

10 Shield, L. \& Weininger, M.J. Collaboration in a Virtual World: Groupwork and the Distance Language Learner. In R. Debski \& M. Levy (Eds.). (2004). World CALL: Global Perspectives on Computer-Assisted Language Learning. The Netherlands:Swets \& Zeitlinger Publishers.

11 Fotos, S. Integrating Grammar Instruction And Communicative Language Use Through Conscious-Raising Tasks. TESOL Quarterly 28(2), (1994), 333. 
penggunaan bahasa otentik. Kern dan Warschauer ${ }^{12}$ menganggap fase ini sebagai penerapan komputer dalam pendidikan bahasa perspektif sosialkognitif. Dalam perspektif ini, Computer Mediated Communication (CMC) telah berkembang. ${ }^{13}$

\section{B. Pembahasan}

\section{Definisi Computer Mediated Communication (CMC)}

Untuk mengerti tentang apa itu Computer Mediated Communication (CMC), berikut definisi dari berbagai perspektif. Istilah Computer Mediated Communication (CMC) pertama kali dikemukakan dan diperkenalkan oleh Hiltz dan Turoff ${ }^{14}$. Mereka memandang CMC sebagai media untuk membuat, memahami, mentransmisikan, mendekodekan, dan menyandikan pesan. Definisi ini telah disetujui oleh berbagai peneliti. Barnes $^{15}$ mendefinisikan CMC sebagai penggunaan berbagai teknologi yang membuka jalan bagi interaksi manusia dan berbagi informasi melalui jaringan komputer yang saling berhubungan termasuk email, discussion group, newsgroup, dan real-time chat. December ${ }^{16}$ juga menyatakan bahwa CMC adalah proses komunikasi manusia melalui komputer, melibatkan orang-orang, yang berada dalam konteks tertentu, dengan menggunakan media untuk berbagai tujuan. Demikian pula, Menurut Warschauer17, "CMC atau komunikasi dalam jaringan mengacu pada kegiatan membaca, menulis dan komunikasi melalui komputer berjaringan internet". 18

12 Kern, R. \& Warschauer, M. Theory And Practice Of Network-Based Language Teaching. In M. Warschauer \& R. Kerns (eds.) Network-based Language Teaching: Concepts and Practice. Cambridge: CambridgeUniversity Press. (2000), 1-19.

13 Müzeyyen Aykaç. Students' and Teachers' Attitudes towards the Use of Computer Mediated Communication Voice \& Text Chat as an Instructional Resource to Improve Speaking Skill. Master Thesis. Bilkent University, Ankara. (2005).

14 Hiltz, S. R., \& Turoff, M.. The Network Nation: Human Communication via Computer. Norwood, NJ: Ablex, (1978). (2002).

15 Barnes, S. Computer-Mediated Communication. Boston, USA: Pearson Publication,

16 December, J. Notes on defining of Computer-Mediated Communication. ComputerMediated Communication Magazine, 4(1), (1997). Retrieved June 18, 2010, from http://www.december.com/cmc/mag/1997/jan/december.htm

17 Warschauer, M. On-line communication. In R. Carter, \& D. Nunan (Eds.), The Cambridge Guide to Teaching English to Speakers of Other Languages, Cambridge: Cambridge University Press. (2001). 207-212.

18 Hosseini, S.B. Computer-Mediated Communication: Pedagogical and Language Learning Implications. International Journal on New Trends in Education and Their Implications, 6.1, (2015), 2-3.

$344 \mid$ JURNAL LISAN AL-HAL 


\section{Karakteristik Computer Mediated Communication (CMC)}

Murray mendefinisikan Computer Mediated Communication (CMC) sebagai "komunikasi yang terjadi antara manusia melalui perangkat komputer ${ }^{19}$. Murray melihat karakteristik CMC sangat penting dalam komunikasi ini, dan juga jika pengajar ingin menggunakan beberapa jenis software CMC di kelas, siswa harus mendapatkan informasi tentang apa yang diharapkan dalam interaksi tersebut. Dalam studinya, Murray menemukan bahwa CMC menunjukkan "... fitur-fitur daftar yang disederhanakan dalam bahasa lisan dan tulis". Dia juga menyampaikan bahwa ada norma-norma khusus yang digunakan dalam CMC. Normanorma ini termasuk penggunaan singkatan, sintaksis yang disederhanakan, penerimaan kesalahan awal, penggunaan simbol seperti emotikon, dan frasa.

Aspek lain dari CMC adalah bahwa struktur percakapan seperti membuka dan menutup percakapan agak berbeda dari percakapan tatap muka. Misalnya, identifikasi diri diperlukan dalam percakapan telepon, tetapi tidak dalam percakapan tatap muka kecuali seseorang bertemu seseorang untuk pertama kalinya. Namun, dalam CMC, itu opsional karena " teknologi secara otomatis mengidentifikasi pengirim dan penerima". ${ }^{20}$

Karakteristik Computer Mediated Communication (CMC) yang lain dalam pembelajaran bahasa yaitu: CMC memungkinkan kegiatan pembelajaran kolaboratif 21 ; CMC mendorong peserta didik untuk mengambil peran aktif dalam komunikasi; CMC memungkinkan peserta didik untuk mengontrol pembelajaran mereka; CMC mendorong siswa untuk lebih sadar diri akan bahasa yang mereka gunakan ${ }^{22}$; CMC memfasilitasi negosiasi makna antar siswa. ${ }^{23}$

19 Murray, D. Protean Communication: The Language of Computer-Mediated Communication. TESOL Quarterly, v34 n3, (2000), 397-421.

${ }^{20}$ Maiko, H. Literature Review: Using Computer-Mediated Communication in Second Language Classrooms. Osaka Keidai Ronshu, v 54, n3, (2003), 115-125.

21 Meskill, C. \& Mossop, J. (Retrieved May 15th, 2003). Technologies Use with Learners of ESL in New York State: Preliminary Report. Retrieved from University of Albany, Language Advocacy Project Website: http://www.albany.edu/lap/Papers/technology\%20use.htm.

22 Bikowski, D. \&Kessler, G.. Making the Most of Discussion Boards in the ESL Classroom. TESOL Journal, v11, n3, (2002). 27-30.

23 Blake. Computer Mediated Communication: a Windown on L2 Spanish Interlanguage. Language Learning \& Technology, v4, n1, May, 2000,120-136. 


\section{Kategori dalam Computer Mediated Communication (CMC)}

Warschauer ${ }^{24}$ menjelaskan 2 mode CMC sebagai berikut: komunikasi bermediasi komputer sinkron/ Synchronous Computer Mediated Communication (SCMC) merupakan komunikasi bermediasi komputer dimana peserta berkomunikasi secara real time melalui chat atau aplikasi diskusi; komunikasi bermediasi komputer asinkron/ Asynchronous Computer Mediated Communication (ACMC) merupakan komunikasi bermediasi komputer di mana peserta berkomunikasi dengan cara yang tertunda oleh komputer, misalnya melalui email; dan membaca dan menulis dokumen online melalui internet.

\section{a. Synchronous Computer Mediated Communication (SCMC)}

Seperti telah dijelaskan sebelumnya, Synchronous Computer Mediated Communication (SCMC)/ Komunikasi Bermediasi Komputer Sinkron merupakan komunikasi yang dilaksanakan secara langsung (online/daring) serempak dalam waktu yang sama atau secara langsung dengan menggunakan komputer. Percakapan dapat didukung secara realtime melalui suara atau dengan diketik. Contoh komunikasi sinkron misalnya menggunakan aplikasi chat (Yahoo Messenger, Google Talk, MIRc dll), video chat (Skype, Line, Facetime, Google+, hangout, dll). Diskusi SCMC memungkinkan peserta didik untuk berkomunikasi serupa dengan konteks Face to Face (FtF) ${ }^{25}$, dan, pada saat yang sama, memberi mereka kesempatan untuk memantau penggunaan bahasa mereka ${ }^{26}$.

Manfaat Synchronous Computer Mediated Communication (SCMC)/ Komunikasi Bermediasi Komputer Sinkron antara lain tidak berhadapan langsung secara fisik, dapat meningkatkan rasa percaya diri peserta didik yang pemalu, dan memungkinkan peserta didik untuk mengikuti perkembangan suatu diskusi tanpa harus datang langsung ke suatu tempat diskusi.

Permasalahan yang mungkin muncul dalam Synchronous Computer Mediated Communication (SCMC)/ Komunikasi Bermediasi Komputer Sinkron misalnya peserta didik sulit untuk melakukan kontak mata dengan tampilan gambar lawan bicara, peserta didik bisa berperilaku

24 Warschauer, M. On-line communication. In R. Carter, \& D. Nunan (Eds.), The Cambridge Guide to Teaching English to Speakers of Other Languages. Cambridge: Cambridge University Press. (2001), 207-212.

25 Lee, L. Online interaction: negotiation of meaning and strategies used among learners of Spanish. ReCALL, 13(02), (2001), 232-244.

26 Sykes, J. Synchronous CMC And Pragmatic Development: Effects Of Oral And Written Chat. The CALICO Journal, 22(3), (2005), 399-431.

$346 \mid$ JURNAL LISAN AL-HAL 
seenaknya jika dipresentasikan dengan avatar (karena tidak terlihat langsung). ${ }^{27}$

\section{b. Asynchronous Computer Mediated Communication (ACMC)}

Asynchronous Computer Mediated Communication (ACMC)/ Komunikasi Bermediasi Komputer Asinkron merupakan komunikasi online/ daring secara tunda dan tidak serempak menggunakan komputer. Komunikasi ACMC berlangsung pada tempat dan waktu berbeda. Contoh komunikasi asinkron ini misalnya menggunakan aplikasi e-mail, video streaming, dll.

ACMC memungkinkan pelajar bahasa untuk mempertimbangkan, meninjau, merevisi atau bahkan membatalkan aliran komunikasi sebelum mengirim informasi kepada penerima ${ }^{28}$. Hal ini membantu pelajar bahasa belajar bagaimana merefleksikan isi dari apa yang akan mereka sampaikan dan kritis terhadap apa yang ada dalam pikiran mereka sebelum mengkomunikasikannya kepada orang lain. Oleh karena itu, teknologi asinkron dapat melibatkan peserta didik dalam proses berpikir kritis $^{29}$ dan pemecahan masalah ${ }^{30}$ dengan komunikasi yang lebih fokus dan terarah.

Manfaat Asynchronous Computer Mediated Communication (ACMC)/ Komunikasi Bermediasi Komputer Asinkron yaitu fleksibel, dapat dibaca kapan saja dan dimana saja dan membuat penugasan pengajar menjadi lebih mudah. Permasalahan yang mungkin muncul dalam Asynchronous Computer Mediated Communication (ACMC)/ Komunikasi Bermediasi Komputer Asinkron misalnya tidak dapat diprediksi kapan bisa mendapat jawaban dan jika jarang dicek bisa terlalu banyak pesan masuk.

\section{Peran pengajar dalam Computer Mediated Communication (CMC)}

Satu pertanyaan instruksional yang sering muncul dalam pembelajaran bahasa online/ daring adalah: di mana pengajar online

27 http://akbar-ila.blogspot.com/2016/10/komunikasi-dalam-jaringan.html

${ }^{28}$ Heisler, J., \& Crabill, S. Who are "Stinkybug" and "packerfan4"? email pseudonyms and participants' perceptions of demography, productivity, and personality. Journal of Computer-Mediated communication, 2(1), (2006).

${ }^{29}$ Lee, L. Learners' Perspectives On Networked Collaborative Interaction With Native Speakers Of Spanish In The Us. Language Learning and Technology, 8(1), (2004), 83-100.

30 Jonassen, D. H, \& Kwon, H. Communication Patterns In Computer-Mediated Versus Face-To-Face Group Problem Solving. Educational Technology Research and Development, 49(10), (2001), 35-52. 
mendapatkan pengalaman awal dan keahlian mereka dalam pengajaran online? Jawaban yang paling umum diberikan adalah "di internet." Jawaban tersebut tidak hanya menyiratkan cara belajar "learning by doing" / belajar sambil melakukan, tetapi juga menyiratkan belajar dari orang lain dengan berbagi pengetahuan dalam komunitas virtual. Literatur tentang penggunaan internet untuk pembelajaran bahasa secara online telah cukup banyak dan bisa dengan mudah dimanfaatkan. ${ }^{31}$

Romiszowski dan Mason ${ }^{32}$ merinci faktor-faktor keberhasilan komunikasi online/daring dalam pembelajaran bahasa Inggris. Meskipun banyak waktu, uang, tenaga, dan komitmen dihabiskan untuk mencoba berkomunikasi secara online, tampaknya upaya ini kurang berhasil. Beberapa faktor umum dalam komunikasi online dalam pembelajaran bahasa Inggris antara lain: teknologi, motivasi, kerangka waktu pembelajaran, dan partisipasi.

Pertama, teknologi. Kecakapan teknologi guru, akses peralatan, dan stabilitas teknologi telah diteliti mempengaruhi keberhasilan komunikasi online dalam pembelajaran bahasa Inggris. Mereka menemukan bahwa tujuan komunikasi online dalam pembelajaran bahasa Inggris dibatasi oleh kesulitan teknis guru. Kedua, motivasi. Para pengajar harus memiliki alasan kuat untuk berkomunikasi satu sama lain sejak awal pembelajaran, maka motivasi pengunaan jaringan internet ditentukan oleh para pengajar sendiri. Ketiga, kerangka waktu pembelajaran. Para pengajar perlu memperhitungkan waktu dengan membuat kerangka waktu dalam rencana pembelajaran untuk keberhasilan komunikasi online dalam pembelajaran bahasa Inggris. Keempat, partisipasi. Mengingat waktu yang tersedia harus digunakan seefisien mungkin dalam komunikasi online tersebut maka partisipasi pengajar dan pembelajar online selayaknya dapat dimaksimalkan.

\section{Strategi-strategi dalam Computer Mediated Communication (CMC)}

Beaudin $^{33}$ mengidentifikasi berbagai teknik yang direkomendasikan dan digunakan oleh instruktur/pengajar bahasa untuk mengajar peserta didik secara online dengan suatu topik selama diskusi Asynchronous Computer Mediated Communicaton (ACMC) dan meneliti

31 Romiszowski, A. J., \& Mason, R. Computer-mediated communication. In d. Jonassen (ed.), handbook of research for educational communications and technology. New York: Simon \& Schuster Macmillan. (1996), 438-456.

32 Romiszowski, A. J., \& Mason, R. Computer-Mediated Communication. (1996).

33 Beaudin, B. P. Keeping Online Asynchronous Discussions On Topic. Journal of Asynchronous Learning Networks, 3(2). (1999).

348 JURNAL LISAN AL-HAL 
faktor-faktor apa yang berpengaruh. Instruktur/pengajar bahasa secara online menilai berikut empat teknik teratas untuk mengajar diskusi online Asynchronous Computer Mediated Communicaton (ACMC): rancang pertanyaan dengan hati-hati yang secara khusus menghasilkan diskusi tentang topik; berikan pedoman untuk membantu pelajar mempersiapkan tanggapan sesuai topik saat online; tulis ulang pertanyaan awal saat respons pelajar mengarah ke arah yang salah saat online; dan berikan ringkasan diskusi secara teratur.

Liu dan Ginther ${ }^{34}$ meninjau faktor verbal dan nonverbal yang mempengaruhi pembentukan kesan pada lingkungan Face to Face (FtF) dan lingkungan Computer Mediated Communication (CMC). Berdasarkan ulasan tersebut strategi pengajaran untuk mencapai komunikasi yang efektif dan kesan positif dalam pembelajaran jarak jauh CMC dikaji. Strategi verbal yang dibahas meliputi: salam pembuka, pengurutan informasi, umpan balik, dan pemberian pujian yang sesuai; menggunakan skema wacana standar - antar jaringan pribadi, retorika, dan narasi — secara selektif, sesuai dengan topik yang dikomunikasikan; menggunakan kode pragmatis dan sintaksis secara selektif; menggunakan bahasa yang intens, seperti pesan-pesan dengan kata-kata yang lugas, untuk mengekspresikan sikap mereka terhadap topik yang dikomunikasikan; menggunakan bahasa langsung; menggunakan berbagai macam kosakata; menggunakan gaya bahasa yang lugas.

Strategi nonverbal yang dibahas meliputi: penggunaan tanda paralinguistik seperti emotikon secara tepat; dengan mempertimbangkan akun kronemik; mempertahankan pengiriman pesan frekuensi tinggi; mempertahankan pesan dengan durasi waktu yang lama; mempertahankan balasan pesan yang cepat; memanipulasi efek utama; memanipulasi efek kebaruan; memastikan tidak ada kesalahan pengetikan. ${ }^{35}$

Campos, Laferrie`re, dan Harasim ${ }^{36}$ menganalisis praktik pengajaran para pengajar post secondary (pendidikan setelah SMA) yang

${ }^{34} \mathrm{Liu}, \mathrm{Y} .$, \& Ginther, D. W. Instructional strategies for achieving a positive impression in computer mediated communication ( $\mathrm{cmc}$ ) distance education courses. Proceedings of teaching, learning, \& technology conference, Middle Tennessee State University, (2002).

35 Romiszowski, A. J., \& Mason, R. Computer-mediated communication. In d. Jonassen (ed.), handbook of research for educational communications and technology. New York: Simon \& Schuster Macmillan, (1996), 438-456.

36 Campos, M., Laferri ere, T., \& Harasim, L. The Post-Secondary Networked Classroom: Renewal of Teaching Practices And Social Interaction. Journal of Asynchronous Learning Networks, 5(2), (2001). 
mengintegrasikan konferensi elektronik asinkron pada lebih dari 100 kegiatan belajar mengajar mode campuran di delapan lembaga pendidikan Amerika Utara antara tahun 1996 dan 1999. Dengan menggunakan metode penelitian kuantitatif dan kualitatif untuk menilai praktik mereka dan untuk lebih memahami hubungan antara penggunaan konferensi elektronik dan tingkat kolaborasi yang dicapai. Berdasarkan temuan, pendekatan pedagogis dalam penggunaan konferensi elektronik dilakukan, dan dikelompokkan sesuai dengan tingkat kolaborasi. Dari hasil dari penelitian ini, penulis menyajikan model yang disarankan untuk kelas online/ daring untuk mendorong dan membimbing transformasi praktik pedagogis.

Penelitian ini menunjukkan bahwa pengajar online mengintegrasikan teknologi konferensi ke dalam pengajaran mereka dengan cara yang kreatif dan dinamis. Hasil penelitian ini menunjukkan penemuan strategi mengajar dengan dukungan teknologi baru. Penulis menyatakan bahwa aktivitas pembelajaran yang paling individual sekalipun dapat menghadirkan kolaborasi online. Temuan ini memberi kesempatan pedagogis melalui teknologi dalam pendidikan dan perubahan pada penggunaan ruang kelas online. Studi ini juga menunjukkan semakin banyak pengalaman online pengajar, semakin sedikit mereka memusatkan perhatian pada proses individu dan semakin mereka mendapat manfaat dari kemungkinan kolaboratif teknologi pembelajaran baru. Temuan dan model ini menyajikan langkah awal untuk mempertimbangkan dinamika desain pembelajaran online. ${ }^{37}$

\section{Berbagai Software Yang Digunakan Dalam Computer Mediated Communication (CMC)}

Saat ini, banyak software atau aplikasi Computer Mediated Communication (CMC) telah diperkenalkan. Orang dapat berkomunikasi melalui komputer dengan banyak cara, misalnya secara tertulis dengan chat, dengan audio dan video yang kesemuanya merupakan lingkungan CMC. Skype, MSN, Facebook, YouTube, dan Twitter adalah beberapa contoh software CMC yang digunakan untuk komunikasi oleh sejumlah besar orang di seluruh dunia ${ }^{38}$. Software ini dapat diterapkan dalam bidang pengajaran dan pembelajaran bahasa Inggris. Pengintegrasian piranti

37 Romiszowski, A. J., \& Mason, R. Computer-mediated communication. In d. Jonassen (ed.), handbook of research for educational communications and technology, (1996).

${ }^{38}$ Hassan, S. M. The Impact of Computer-Mediated Communication Environments on Foreign Language Learning: a Review of the Literature. Teaching English with Technology, 14(2), (2015), 67-86.

$350 \mid$ JURNAL LISAN AL-HAL 
tersebut menciptakan peluang baru bagi guru dan pelajar bahasa untuk berkomunikasi bahkan ketika berada di luar kelas. Secara teknis, setiap software memiliki fitur uniknya sendiri yang berbeda dengan software CMC yang lain. Berikut penjabaran beberapa software atau aplikasi yang digunakan dalam CMC:

\section{a. Skype}

Skype adalah layanan internet yang menyediakan jendela chatting/ obrolan audio dan video. Pengguna dapat mengatur panggilan konferensi dengan banyak orang secara bersamaan. Skype adalah software yang sangat berguna untuk pembelajaran bahasa Inggris. Robert ${ }^{39}$ menemukan bahwa Skype memberikan kesempatan menarik bagi para profesional dan pelajar bahasa Inggris, karena software ini menyediakan channel/ saluran tambahan untuk komunikasi lisan. Skype juga merupakan software yang efektif untuk guru bahasa Inggris. Develotte, Guichon \& Vincent ${ }^{40}$ mengeksplorasi bagaimana guru bahasa Inggris belajar untuk mengajar dengan pengaturan synchronous multimodal pada Skype, dengan fokus khusus pada penggunaan webcam selama interaksi pedagogis. Hasilnya menunjukkan bahwa penggunaan webcam memungkinkan interaksi yang intens dan menambah perasaan kehadiran bersama. Yanguas ${ }^{41}$ meneliti bagaimana siswa berlajar bahasa Inggris dalam kelompok CMC video dan kelompok CMC audio bernegosiasi makna selama task-based interaction/ interaksi berbasis tugas menggunakan Skype. Skype digunakan oleh para siswa untuk melakukan percakapan mereka di laboratorium bahasa. Hasilnya menunjukkan bahwa penggunaan Skype untuk kelompok CMC audio menciptakan pola turn-taking/ pengambilan giliran yang hampir sama dengan pola pengambilan giliran pada kelompok CMC video. Suk, Young \& Vrongistinos ${ }^{42}$ meneliti software Blackboard dan Skype berbasis sistem pendampingan elektronik untuk guru pemula. Mereka mendapati penggunaan software Blackboard dan Skype secara bersamaan

39 Robert, G. J. Emerging Technologies Skype And Podcasting: Disruptive Technologies For Language Learning. Language Learning \& Technology 9(3), (2005), 912.

40 Develotte, C., Guichon, N., \& Vincent, C. The Use Of The Webcam For Teaching A Foreign Language In A Desktop Videoconferencing Environment. ReCALL 22 (3), (2010). 293-312.

41 Yanguas, I. Oral Computer-Mediated Interaction Between L2 Learners: It's About

Time! Language Learning \& Technology 14(3), (2010). 72-93, http://llt.msu.edu/issues/october2010/yanguas.pdf.

42 Suk, H., Young, \&, Vrongistinos, K. Using Blackboard And Skype For Mentoring Beginning Teachers. American Journal of Distance Education 26(3), (2012), 172-179. 
bermanfaat untuk memulai pembelajaran bahasa Inggris secara efektif oleh para guru.

\section{b. Facebook}

Facebook adalah layanan jejaring sosial yang diluncurkan pada Februari 2004. Dalam pembelajaran bahasa Inggris, Facebook memfasilitasi interaksi antara siswa dan guru serta interaksi antar siswa. Penggunaan Facebook dalam pembelajaran bahasa Inggris telah diteliti dalam sejumlah penelitian. Kamarul, Norlida \& Zainol ${ }^{43}$ meneliti bahwa siswa menganggap Facebook sebagai lingkungan belajar yang berguna dan bermakna yang dapat mendukung, meningkatkan dan memperkuat pembelajaran bahasa Inggris. Penelitian ini menyatakan bahwa para siswa percaya Facebook dapat digunakan sebagai lingkungan online untuk memfasilitasi pembelajaran bahasa Inggris. Namun demikian, para guru harus mengintegrasikan Facebook sebagai rencana pembelajaran dengan tujuan dan hasil pembelajaran yang telah ditentukan sebelumnya agar pengalaman belajar siswa menjadi bermakna. Mitchell ${ }^{44}$ meneliti motivasi siswa untuk bergabung dengan Facebook. Para siswa dalam penelitian tersebut bergabung dengan Facebook karena alasan sosial. Hasil penelitian menunjukkan bahwa melalui Facebook siswa dapat berkomunikasi dengan teman-teman yang ada sekaligus belajar bahasa Inggris, dan belajar tentang budaya Amerika. Mereka dapat mencapai tujuan pembelajaran dengan Facebook tanpa kesulitan berarti.

\section{c. YouTube}

YouTube adalah situs web berbagi video yang dibuat pada Februari 2005, yang tentunya juga dapat digunakan untuk tujuan pembelajaran bahasa Inggris. Beberapa penelitian dilakukan untuk menguji dampak YouTube dalam pembelajaran bahasa Inggris. Miller, Hafner \& Fun ${ }^{45}$ mempresentasikan pendekatan baru desain pembelajaran Bahasa Inggris untuk Tujuan Akademik/ English for Academic Purposes (EAP). Para siswa melakukan percobaan ilmiah sederhana serta mendokumentasikan

${ }^{43}$ Kamarul, M. K., Norlida, A., \& Zainol, A. M.J. Z. Facebook: An online environments for learning English in institutions of higher education. The Internet and Higher Education, 75(4), (2010), 179-187.

44 Mitchell, K. A Social tool: Why and how ESOL students use Facebook. CALICO Journal 29(3), (2012), 471-493.

45 Miller, L., Hafner, C. A., \& Fun, C. N. K. Project-Based Learning In A Technologically Enhanced Learning Environment For Second Language Learners: Students' Perceptions. ELearning and Digital Media 9(2), (2012), 183-195.

\footnotetext{
$352 \mid$ JURNAL LISAN AL-HAL
} 
prosedur, hasil dan menginterpretasikannya dalam bentuk video digital yang diunggah dan dibagikan melalui YouTube. Penggunaan film dokumenter ilmiah multimodal ini sebagai alat pedagogis dalam English for Academic Purposes (EAP) yang dilaporkan dengan mengacu pada data yang diambil dari kuesioner siswa, wawancara dengan siswa, dan komentar siswa dalam weblog pembelajaran. Temuan menunjukkan bahwa siswa merasakan nilai-nilai linguistik dan teknis dalam kegiatan konstruksi dan berbagi film dokumenter ilmiah multimodal tersebut. Hafner \& Miller ${ }^{46}$ menciptakan proyek video digital yang berpusat pada siswa, di mana siswa membuat dan berbagi film dokumenter ilmiah multimodal. Sejumlah teknologi baru dan platform Web 2.0 (termasuk YouTube dan Edublog) diintegrasikan ke dalam prosesnya untuk menciptakan lingkungan belajar yang kaya akan teknologi.

\section{d. Wiki}

Implementasi Wiki dalam pembelajaran bahasa Inggris juga telah mendapat perhatian dalam beberapa tahun terakhir. Castaneda ${ }^{47}$ meneliti perbedaan tingkat pencapaian antara siswa yang menggunakan instruksi dengan blog video/foto dan wiki, dibandingkan dengan siswa yang menggunakan instruksi dengan teknologi berbasis teks tradisional. Hasil penelitian menunjukkan bahwa tidak ada perbedaan yang signifikan pada tingkat produksi antara siswa yang menggunakan blog video/foto dan wiki dengan siswa yang menggunakan teknologi tradisional. Namun, perbedaan signifikan ditemukan pada tingkat pengenalan untuk kelompok yang menggunakan blog video / foto dan wiki bila dibandingkan dengan mereka yang menggunakan teknologi tradisional. Hasil rata-rata umum mengungkapkan bahwa kelompok yang menggunakan blog video / foto dan wiki mengungguli mereka yang menggunakan teknologi tradisional.

Stickler \& Hampel ${ }^{48}$ meminta beberapa peserta didik untuk ikut serta dalam kursus bahasa Inggris intensif secara online yang

46 Hafner, C. A., \& Miller, L. Fostering learner autonomy in english for science: a collaborative digital video project in a technological learning environment. Language Learning \& Technology 15(3), (2011), 68-86.

47 Castaneda, D. A. The Effects Of Instruction Enhanced By Video/Photo Blogs And Wikis On Learning The Distinctions Of The Spanish Preterite And Imperfect. Foreign Language Annals 44(4), (2011), 692-711.

48 Stickler, U., \& Hampel, R. Cyberdeutsch: Language Production And User Preferences In A Moodle Virtual Learning Environment. CALICO Journal 28(1), (2010), 4973. 
dikhususkan bagi siswa tingkat menengah. Kursus ini menguji cobakan penggunaan lingkungan belajar virtual berbasis Moodle dan berbagai alat online baru yang cocok untuk berbagai jenis kegiatan pembelajaran bahasa (misalnya wiki untuk pembelajaran kolaboratif dan blog untuk pembelajaran reflektif). Hasil penelitian ini menunjukkan bahwa kursus bahasa Innggris online dapat menggabungkan berbagai pendekatan belajar dan mengajar, seperti menggunakan bahasa secara komunikatif dan berfokus pada bentuk dan praktik bahasa.

\section{e. Blog}

Blog memiliki beberapa manfaat dalam pembelajaran bahasa, yang telah diuji dalam beberapa penelitian, misalnya penelitian Hsu, Wang \& Comac $^{49}$. Mereka meneliti bagaimana penggunaan blog audio dapat membantu memenuhi kebutuhan instruktur/ pengajar bahasa Inggris untuk meningkatkan kualitas pengajaran bahasa Inggris sebagai bahasa kedua (ESL). Instruktur menggunakan blog audio untuk mengelola tugas lisan, berinteraksi dengan peserta didik, dan mengevaluasi hasil pekerjaan peserta didik. Hasil penelitian menunjukkan bahwa penggunaan blog audio memenuhi kebutuhan pengajaran, menyediakan cara yang efisien dan efektif untuk mengevaluasi tugas lisan siswa dan memungkinkan feedback/ umpan balik lisan secara individu. Selain itu, peserta didik menikmati kemudahan menggunakan blog audio dan mereka menyatakan bahwa blog audio mendorong pengalaman belajar bahasa Inggris mereka.

\section{Computer Mediated Communication (CMC) dalam Communicative Language Teaching (CLT)}

Dalam pembelajaran bahasa Inggris dengan komunikasi bermediasi komputer, komputer berfungsi sebagai alat untuk interaksi komunikatif. Oleh karena itu, ada hubungan erat antara komunikasi bermediasi komputer/ Computer Mediated Communication (CMC) dan pendekatan komunikatif dalam pembelajaran bahasa asing khususnya bahasa Inggris. Dalam pendekatan komunikatif, pemahaman input - listening dan reading - diperlukan untuk keseluruhan proses penguasaan bahasa Inggris. Namun, seperti dicatat oleh Swain ${ }^{50}$, pemahaman input saja tidak cukup

${ }^{49}$ Hsu, H. Y, Wang, S. K. \& Comac, L. Using Audio Blogs To Assist English-Language Learning: An Investigation Into Student Perception. Computer Assisted Language Learning 21(2), (2008)., 181-198.

50 Swain, M. Communicative Competence: Some Roles Of Comprehensible Input And Comprehensible Output. In S. Gass \& C. Madden (Eds.), Input In Second Language Acquisition, Rowley, MA: Newbury House. (1985), 235-253.

354 JURNAL LISAN AL-HAL 
untuk penguasaan bahasa Inggris. Output siswa - writing dan speaking juga merupakan aspek penting dalam penguasaan bahasa Inggris. Penggunaan komputer dalam aktivitas komunikasi bahasa Inggris bermediasi komputer menyediakan input dan output, yang keduanya diperlukan untuk kemajuan siswa dalam pembelajaran bahasa Inggris ${ }^{51}$. Hampel dan Hauck ${ }^{52}$ menyimpulkan bahwa kegiatan pembelajaran bahasa Inggris berbasis internet memungkinkan siswa untuk berinteraksi dan menegosiasikan makna dengan siswa lain, karena mereka perlu bertukar informasi dalam bahasa Inggris.

Oleh karena itu Communicative Language Teaching (CLT) menekankan pada aspek komunikasi, interaksi, dan pengembangan kompetensi kebahasaan, serta keterampilan berbahasa (menyimak, membaca, menulis, berbicara) sebagai tujuan pembelajaran bahasa. Maka dalam penerapannya memiliki unsur penting, antara lain mengutamakan makna sebenarnya daripada tata gramatikalnya; adanya kegiatan komunikasi fungsional dan interaksi sosial yang saling berkaitan; pembelajaran berorientasi pada pemerolehan kompetensi komunikatif, bukan ketepatan gramatikal; pembelajaran diarahkan pada partisipasi siswa dalam menemukan kaidah bahasa lewat kegiatan berbahasa (learning by doing); materi pembelajaran berangkat dari analisis kebutuhan berbahasa dalam pembelajaran.

\section{Simpulan}

Computer Mediated Commmunication (CMC) merupakan komunikasi manusia yang terjadi melalui penggunaan dua atau lebih perangkat elektronik. Terdapat dua mode Computer Mediated Commmunication (CMC) yaitu: Synchronous Computer Mediated Communication (SCMC)/ komunikasi bermediasi komputer sinkron merupakan komunikasi bermediasi komputer dimana peserta online berkomunikasi secara real time; dan Asynchronous Computer Mediated Communication (ACMC)/ komunikasi bermediasi komputer asinkron merupakan komunikasi bermediasi komputer di mana peserta berkomunikasi dengan cara yang tertunda oleh komputer.

Ada beberapa faktor yang mempengaruhi keberhasilan komunikasi

51 Sotillo, M.S. (2000). Discourse functions and syntactic complexity in synchronous, and asynchronous communication. Language Learning \& Technology, 4(1), pp. 82-119.

${ }^{52}$ Hampel, R. \& Hauck, M. (2004) Towards an effective use of audio conferencing in distance language courses, Language Learning and Technology 8 (1), pp. 66-82, (online at: http://llt.msu.edu/vol8num1/hampel/default.html). 
online/daring dalam pembelajaran bahasa Inggris yaitu antara lain: pertama, kecakapan teknologi guru, akses peralatan, dan stabilitas teknologi atau internet. Tujuan komunikasi online dalam pembelajaran bahasa Inggris dibatasi oleh kesulitan teknis pengajar bahasa Inggris. Kedua, para pengajar juga harus memiliki alasan yang kuat untuk berkomunikasi satu sama lain sejak awal pembelajaran, maka motivasi pengunaan jaringan internet ditentukan oleh para pengajar sendiri. Ketiga, para pengajar perlu memperhitungkan waktu dengan membuat kerangka waktu dalam rencana pembelajaran untuk keberhasilan komunikasi online dalam pembelajaran bahasa Inggris. Keempat, mengingat waktu yang tersedia harus digunakan seefisien mungkin dalam komunikasi online tersebut maka partisipasi pengajar dan peserta didik online dalam kelas bahasa selayaknya dapat maksimal.

\section{DAFTAR PUSTAKA}

Barnes, S. Computer-Mediated Communication. Boston, USA: Pearson Publication. 2002.

Beaudin, B. P. Keeping Online Asynchronous Discussions On Topic. Journal of asynchronous learning networks, 3(2), 1999. From http://www.aln.org/alnweb.journal/

Bikowski, D. \&Kessler, G. Making the Most of Discussion Boards in the ESL Classroom. TESOL Journal, v11, n3, 2002.

Blake, Computer Mediated Communication: a Window on L2 Spanish Interlanguage, 2000.

Boone, K. C. Speech or writing? Email as a new medium. Liberal Education, 87(3), 2001.

Campos, M., Laferri ere, T., \& Harasim, L. The Post-Secondary Networked Classroom: Renewal of Teaching Practices And Social Interaction. Journal of Asynchronous Learning Networks, 5(2), 2001. From http://www.aln.org/alnweb/journal/

Castaneda, D. A. The Effects Of Instruction Enhanced By Video/Photo Blogs And Wikis On Learning The Distinctions Of The Spanish Preterite And Imperfect. Foreign Language Annals 44(4), 2011.

December, J. Notes on defining of Computer-Mediated Communication. Computer-Mediated Communication Magazine, 4(1), 1997.

Develotte, C., Guichon, N., \& Vincent, C. The Use Of The Webcam For Teaching A Foreign Language In A Desktop Videoconferencing Environment. ReCALL 22(3), 2010.

$356 \mid$ JURNAL LISAN AL-HAL 
Fey, M. Critical Literacy In School-College Collaboration Through Computer Networking: A Feminist Research Project. Journal of Literacy Research, 30(1), 1998.

Fotos, S. Integrating Grammar Instruction And Communicative Language Use Through Conscious-Raising Tasks. TESOL Quarterly 28(2), 1994.

Hafner, C. A., \& Miller, L. Fostering Learner Autonomy In English For Science: A Collaborative Digital Video Project In A Technological Learning Environment. Language Learning \& Technology 15(3), 2011.

Hampel, R. \& Hauck, M. Towards An Effective Use Of Audio Conferencing In Distance Language Courses, Language Learning and Technology 8 (1), 2004.

Hassan, S. M. The Impact of Computer-Mediated Communication Environments on Foreign Language Learning: a Review of the Literature. Teaching English with Technology, 14(2), 2015.

Heisler, J., \& Crabill, S. Who are "stinkybug" and "packerfan4"? Email pseudonyms and participants' perceptions of demography, productivity, and personality. Journal of Computer-Mediated communication, 2(1), 2006.

Herring, Susan C. Computer-Mediated Communication, Linguistic, Social and Cross-Cultural Perspectives, Amsterdam: John Benjamin Publishing Company, 1996.

Hiltz, S. R., \& Turoff, M. The Network Nation: Human Communication via Computer. Norwood, NJ: Ablex, 1978.

Hosseini, S.B. Computer-Mediated Communication: Pedagogical and Language Learning Implications. International Journal on New Trends in Education and Their Implications, 6.1, 2015.

Hsu, H. Y, Wang, S. K. \& Comac, L. Using Audio Blogs To Assist EnglishLanguage Learning: An Investigation Into Student Perception. Computer Assisted Language Learning 21(2), 2008.

Jonassen, D. H, \& Kwon, H. Communication Patterns In Computer-Mediated Versus Face-To-Face Group Problem Solving .Educational Technology Research and Development, 49(10), 2001.

Kamarul, M. K., Norlida, A., \& Zainol, A. M.J. Z. Facebook: An Online Environments For Learning English In Institutions Of Higher Education. The Internet and Higher Education, 75(4), 2010.

Kern, R. \& Warschauer, M. Theory and practice of network-based language teaching. In M. Warschauer \& R. Kerns (eds.) Network-based Language Teaching: Concepts and Practice. Cambridge: Cambridge University Press, 2000. 
Kern, R. G. Restructing Classroom Interaction With Networked Computers: Effects On Quantity And Characteristics Of Language Production. The Modern Language Journal, 79(4), 1996.

Lee, L. Learners' Perspectives On Networked Collaborative Interaction With Native Speakers of Spanish In The Us. Language Learning and Technology, 8(1), 2004.

Lee, L. Online Interaction: Negotiation Of Meaning And Strategies Used Among Learners Of Spanish. ReCALL, 13(02), 2001.

Liu, Y., \& Ginther, D. W. Instructional Strategies For Achieving A Positive Impression In Computer Mediated Communication (CMC) Distance Education Courses. Proceedings of Teaching, Learning, \& Technology Conference, Middle Tennessee State University, 2002.

Maiko, H. Literature review: using computer-mediated communication in second language classrooms. Osaka Keidai Ronshu, v 54, n3, 2003.

Meunier, L. E. Personality Differences And Motivational Factors In Distance Learning. In F. Borchardt, C. Bradin, \& E. Jonhson (Eds.), Distance learning, Proceedings of the Computer Assisted Language Instruction Consortium 1996 Annual Symposium. Albuquerque, NM: The University of New Mexico, 1996.

Miller, L., Hafner, C. A., \& Fun, C. N. K. Project-based learning in a technologically enhanced learning environment for second language learners: Students' perceptions. E-Learning and Digital Media 9(2), 2012.

Mitchell, K. A Social tool: Why and how ESOL students use Facebook. CALICO Journal 29(3), 2012.

Murray, D. Protean Communication: The Language of Computer-Mediated Communication. TESOL Quarterly, v34 n3, 2000.

Müzeyyen Aykaç. Students' and Teachers' Attitudes towards the Use of Computer Mediated Communication Voice \& Text Chat as an Instructional Resource to Improve Speaking Skill. Master Thesis. Bilkent University, Ankara, 2005.

Quan-Hasse, A., Cothrel, J., \& Wellman, B. Instant Messaging for Collaboration: A Case Study of a High-Tech Firm. Journal of Computer Mediated Communications, 10(4), 2005.

Robert, G. J. Emerging Technologies Skype And Podcasting: Disruptive Technologies For Language Learning. Language Learning \& Technology 9(3), 2005.

Romiszowski, A. J., \& Mason, R. Computer-mediated communication. 1996. In D. Jonassen (Ed.), Handbook of research for educational communications and technology. New York: Simon \& Schuster

358 JURNAL LISAN AL-HAL 
Macmillan.

Selinger, M. Forming a critical community through telematics. Computers Education, 30 (1/2), 1998.

Shield, L. \& Weininger, M.J. Collaboration in a Virtual World: Groupwork and the Distance Language Learner. In R. Debski \& M. Levy (Eds.). World CALL: Global Perspectives on Computer-Assisted Language Learning. The Netherlands:Swets \& Zeitlinger Publishers, 2004.

Sotillo, M.S. Discourse Functions And Syntactic Complexity In Synchronous, And Asynchronous Communication. Language Learning \& Technology, 4(1), 2000.

Stickler, U., \& Hampel, R. Cyberdeutsch: Language Production And User Preferences In A Moodle Virtual Learning Environment. CALICO Journal 28(1), 2010.

Swain, M. Communicative Competence: Some Roles Of Comprehensible Input And Comprehensible Output. In S. Gass \& C. Madden (Eds.), Input in Second Language Acquisition, Rowley, MA: Newbury House, 1985.

Sykes, J. Synchronous Cmc And Pragmatic Development: Effects Of Oral And Written Chat. The CALICO Journal, 22(3), 2005.

Tanian, S. \& James, K. Could oral communication skills become a casualty of online learning?: a future scenario that could prevent this. Herdsa 2002 conference, 2002.

Warschauer, M. Motivational Aspects Of Using Computers For Writing And Communication. In M. Warschauer (Ed.), Telecollaboration In Foreign Language Learning: Proceedings of the Hawai'i Symposium. Honolulu: University of Hawai'i, Second Language Teaching \& Curriculum Center, 1996.

Warschauer, M. On-line communication. In R. Carter, \& D. Nunan (Eds.), The Cambridge Guide to Teaching English to Speakers of Other Languages. Cambridge: Cambridge University Press, 2001. 


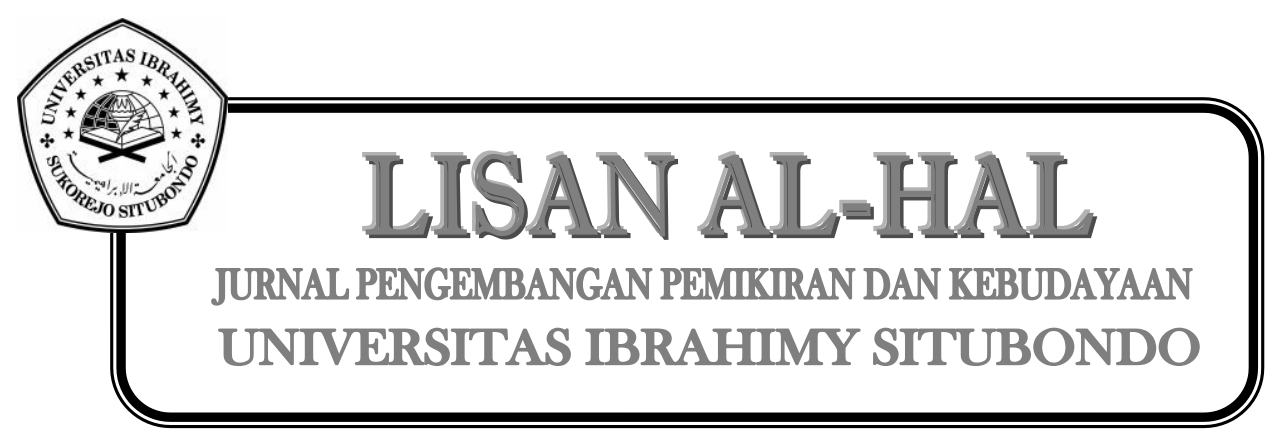

360 JURNAL LISAN AL-HAL 